\title{
Donor Advised Funds: What Can North America Learn From the Australian Approach?
}

\section{Ian Murray"}

Charity law is a public and private hybrid that seeks to balance donor intent with the achievement of public benefit. In supporting that balance, regulatory frameworks typically intrude less on donor intent when the recipient charity is a publicly controlled charity, rather than a private foundation. This approach is challenged by the rise of donor advised funds - public charity intermediaries that behave in many ways like privately controlled foundations. The rise has been particularly marked in the United States, but is also apparent in Canada and Australia. Pertinently, while Australia took many years to regulate private foundations, it shortly afterwards also introduced specific rules for public charitable foundations. This article therefore examines whether the United States and Canada can draw guidance from Australia's experience in dealing with donor advised funds, especially in relation to delay in distributions and conficts of interest.

Associate Professor of University of Western Australia. Deputy Head of School - Research, Faculty of Arts, Business, Law and Education, Law School, Dr. BSc LLB W Aust, LLM (Taxation) NSW, PhD Tas. ORCID 0000-0001-7896-3550. Many thanks to Tayu Wilker for invaluable research assistance and commentary. 
I. INTRODUCTION

II. Donor Advised Funds
A. The Characteristics of DAFs
B. Advantages
C. Disadvantages

1. Delay

2. Conflicts of Interest

3. Transparency and Accountability

III. The Australian Context
A. Regulation of the Charity Sector
B. Ancillary Funds
C. DAFs or "Sub-funds"

IV. Aspects of the Australian Rules that May Help Address DAF Problems

A. Dealing with Delay in Distributions/Public Benefit

1. Minimum Distribution Requirements

2. No Circular Distributions to Other Philanthropic Intermediaries

B. Addressing Conflicts of Interest

\title{
V. Conclusion
}

\section{Introduction}

\begin{abstract}
Charity law is a hybrid of private and public law. ${ }^{1}$ Unlike private law's starting position of freedom, public law typically requires that actions be justified by some positive law, and so unfettered donor freedom is not an appropriate frame of reference. ${ }^{2}$ After all, charity law itself comprises a framework of rights and obligations that a donor/creator selects when creating a charity. That framework reflects a tension between respecting donor and charity controller intent and overriding donor/
\end{abstract}

1. See generally Kathryn Chan, The Public-Private Nature of Charity Law (Oxford: Hart Publishing, 2016).

2. Ibid at 11 . 
charity controller intent to achieve a greater or fairer public benefit. ${ }^{3}$ The framework of rights and obligations is usually more supportive of donors when it is a publicly controlled charity to which they donate, rather than a privately controlled charity. However, recent times have seen the rise, in the United States, Canada, Australia and other jurisdictions of public charities acting like private foundations, such as donor advised funds (“DAF"s).

This article examines the issue of privately influenced public charities in the form of DAF sponsors. It does so by asking what the United States and Canada can learn from Australia's approach to dealing with public charity philanthropic intermediaries. Although Australia took more than 50 years longer than the United States to introduce a specific regulatory regime for private charitable foundations, it relatively swiftly followed this step with rules for public charity intermediaries modelled on those applying to private foundations.

To identify focal areas in which the Australian rules might help, as well as limits based on differing circumstances, Part II sketches the current nature and trajectory of DAFs in the United States and Canada and examines key problems that have emerged. Part III describes the Australian regulation of public charity intermediaries and of DAFs in particular. Aspects of the Australian regime are then considered in Part IV as potential methods to address the key issues of delay in distributions and achievement of public benefit, and of conflicts of interest. Part V concludes.

3. In the context of $c y$-près, see Mark Ascher, Austin Wakeman Scott \& William Fratcher, Scott and Ascher on Trusts, 5d (New York: Aspen Publishers, 2006) at $\$ \$ 39.5,39.5 .4$; UK, Report of the Committee on the Law and Practice Relating to Charitable Trusts, Cmd 8710 (1952) at 16-7, 23-28, 75 (Lord Nathan). More broadly, see ibid at 12-13. 


\section{Donor Advised Funds}

A DAF is a named management account within a charitable foundation (usually a public charitable trust or corporation). ${ }^{4} \mathrm{~A}$ donor makes a gift of property to the charitable foundation and typically obtains a tax deduction or credit. While the donor retains no ownership interest in the property transferred and has no legal power to direct the charitable foundation's dealings with the property, the charitable foundation provides administrative and investment assistance to the donor and gives the donor advisory privileges about how it should deal with the donated property. ${ }^{5}$ The charitable foundation thus often acts in accordance with the donor's wishes about when and to which entities it distributes the donated property. The commercial imperative for charitable foundations to act in accordance with donors' wishes is emphasised where financial services firms provide DAF services as part of their wealth management operations, which is the case for some of the largest DAF sponsors such as Fidelity Charitable. Indeed, the growth of DAF sponsors, especially those affiliated with financial services firms, has surged in the United States. Drew Lindsay in the Chronicle of Philanthropy found that in 2017, three of the top five DAF providers were financial services firm affiliates and the largest, Fidelity Charitable, raised more than double

4. As to the characteristics of DAFs, see especially Canada, Senate, Report of the Special Senate Committee on the Charitable Sector, Catalyst for Change: A Roadmap to a Stronger Charitable Sector (June 2019), (Chair: The Honourable Terry M Mercer) at 109-13, online (pdf): Senate of Canada <sencanada.ca/content/sen/committee/421/CSSB/ Reports/CSSB_Report_Final_e.pdf> [Catalyst for Change]; US, Internal Revenue Service, “Donor Advised Funds” (26 March 2019), online: Internal Revenue Service <www.irs.gov/charities-non-profits/charitableorganizations/donor-advised-funds $>$; Michael J Hussey, "Avoiding Misuse of Donor Advised Funds" (2010) 58:1 Cleveland State Law Review 59 at 60-61, 64-65; see also Internal Revenue Code, 26 USC, $\$$ 4966(d)(2) (2019) [IRC].

5. Catalyst for Change, supra note 4; Internal Revenue Service, ibid. 
the non-DAF top fundraising charity. ${ }^{6}$ United States DAF sponsors held over USD $\$ 110$ billion of assets in 2017, which was around one-eighth of private foundation assets, ${ }^{7}$ but as just noted, DAF sponsors are some of the fastest growing charities in the country. Financial service linked DAFs also hold a material, albeit lower, proportion of DAF assets in Canada. $^{8}$

Nevertheless, as demonstrated by the Fairbairn $v$ Fidelity Charitable lawsuit, ${ }^{9}$ donors have less control over a DAF than over a private foundation of which they are the trustee or a director of the trustee company. Further, not all DAF providers are linked to financial services firms. A number of large national providers are independent of financial services firms, such as the National Philanthropic Trust and the National Christian Foundation. ${ }^{10}$ Community foundations, which are charities with a purpose focused on a particular geographic region, are also prominent. The Silicon Valley Community Foundation raises a comparable amount to the large financial services DAF providers, ${ }^{11}$ although many community foundations are much smaller. In Canada,

6. Drew Lindsay, “America's Favorite Charities 2018” (2018) 31:1 Chronicle of Philanthropy 9. Fidelity Charitable raised USD $\$ 6.8$ billion, Schwab Charitable USD \$3.1 billion and Vanguard Charitable USD \$1.5 billion. The largest non-DAF fundraiser, United Way, raised USD \$3.26 billion, followed by the Salvation Army with USD \$1.47 billion.

7. National Philanthropic Trust, "2018 Donor-Advised Fund Report" (2018) at 12-13, online: National Philanthropic Trust <www.nptrust.org/ reports/daf-report/>.

8. In the Canadian context, see Canada, Senate, Special Committee on the Charitable Sector, Minutes of Proceedings, 42:1, No 6 (18 September 2018) at 80 (Keith Sjogren, Strategic Insight), online (pdf): <sencanada. $\mathrm{ca} /$ Content/SEN/Committee/421/cssb/pdf/06issue.pdf> [Sjogren].

9. Fairbairn v Fidelity Investments Charitable Gift Fund, 2018 WL 6199684 (ND Cal 2018) [Fairbairn]. Paul Sullivan, "Lawsuit Could Cool a Fast-Growing Way of Giving to Charities" (31 May 2019), online: New York Times <www.nytimes.com/2019/05/31/your-money/donor-advisedfunds-charitable-giving-lawsuit.html>. The dispute relates to the speed with which Fidelity Charitable disposed of donated shares.

10. Lindsay, supra note 6 .

11. Ibid. There was USD \$1.4 billion raised in 2017 . 
community foundations hold around half of all DAF assets. ${ }^{12}$ In addition, some non-philanthropic intermediaries, such as universities, also provide DAFs alongside their various other activities; they are commonly labelled "single-issue charities". ${ }^{13}$ Nevertheless, viewed on its own, every DAF management account is effectively a philanthropic intermediary.

\section{A. The Characteristics of DAFs}

Roger Colinvaux has written incisively on DAFs, examining them as alternatives to private foundations, as public charity substitutes and as instigators of new donations. ${ }^{14}$ Each of these perspectives is valid, albeit the increase in the size of DAFs seems to be far outstripping their likely impact in generating new donations. ${ }^{15}$ Further, the public charity substitution effect can be viewed as a temporal substitution. Colinvaux focuses on whether gifts are made to DAFs in substitution for other charities, an outcome that Colinvaux characterises as more prominent for pure fundraising DAF sponsors such as Fidelity Charitable, than for single-issue charities or community foundations. ${ }^{16}$ However, all DAFs involve some level of temporal deferral because they are intermediaries

12. Sjogren, supra note 8 at 80 .

13. National Philanthropic Trust, supra note 7 at 40-46.

14. Roger Colinvaux, "Donor Advised Funds: Charitable Spending Vehicles for $21^{\text {st }}$ Century Philanthropy” (2017) 92:1 Washington Law Review 39 [Colinvaux, "Donor Advised Funds"].

15. Compare ibid at 60 .

16. Ibid at 54-58. 
- they add an extra step before funds can be deployed more actively. ${ }^{17}$ Of course, charities that are not foundations do not always immediately and directly apply their assets to their purposes. Nevertheless, adding an extra step would mean a slower application of assets to purposes when compared to direct donation to the same ultimate recipient, unless the DAF can speed up the process somehow, for instance by faster and better realisation of non-liquid assets.

This article focuses on DAFs as quasi-private foundation substitutes and as temporal substitutes and examines their advantages and disadvantages from that perspective. However, it does so without losing sight of the fact that DAFs potentially serve a role in raising the overall level of donations to charity, such that the advantages of DAFs should not be unduly eliminated.

17. Ibid at 55-58. Colinvaux does discuss deferral, but does so in the context of national DAF sponsor organisations like Fidelity Charitable. I think, as Adam Parachin appears to do, that it is not possible to characterise intermediaries such as national DAF sponsor organisations in the way that Colinvaux does as "not hav[ing] an independent substantive charitable purpose or goal" (ibid at 55). Rather, all charities have an overarching purpose and must select (different) means to achieve that purpose and those means are characterized as charitable or not by reference to the overarching purpose. See Canada, Senate, Proceedings of the Special Senate Committee on the Charitable Sector Transcript, 42:1, No 14 (8 April 2019) (Adam Parachin, Osgoode Hall Law School), online: Senate of Canada <sencanada.ca/en/Content/SEN/Committee/421/cssb/14ev-54665-e>. The issue of deferral is equally pertinent for all charities, although some charities raise particular risks. 


\section{B. Advantages}

DAFs are administratively simpler and less costly than establishing a separate private foundation. ${ }^{18}$ Yet they still permit a high degree of the flexibility, control and donor (and the donor's family) involvement in decisions about the use of DAF funds. ${ }^{19}$ In the United States and Canada, there are also more restrictive rules that reduce the deduction to a private foundation in some circumstances, but which do not apply to donations to DAFs, especially non-cash gifts. ${ }^{20}$ Indeed, many DAFs, especially national sponsor organisations, claim that they are more experienced with handling non-cash gifts and thus achieve lower transaction costs. ${ }^{21}$ United States private foundations are also subject to excise taxes on investment income and a payout requirement, whereas DAFs are not. ${ }^{22}$ Additionally, from a tax administrator's perspective, there are cost advantages in regulating a smaller number of large DAF

18. Catalyst for Change, supra note 4 at 109-10; Charlotte Cloutier, "DonorAdvised Funds in the US: Controversy and Debate" (2005) 19:2 The Philanthropist 85 at 89; Victoria B Bjorklund, "The Rise of DonorAdvised Funds: Why Congress Should Not Respond” (Paper delivered at the Boston College Law School Forum on Philanthropy and the Public Good Conference on The Rise of Donor-Advised Funds: Should Congress Respond?, Washington, DC, 23 October 2015) at 71, online: Digital Commons <lawdigitalcommons.bc.edu/philanthropy-forum/ donoradvised2015/papers/6/>; Janet Bandera, "Summarizing the Differences Between Private Foundations and Donor-Advised Funds Helps Determine Which Approach Works Best for Donors and Donor Families" (2008) 25:4 Journal of Taxation of Investments 90.

19. Cloutier, ibid at 88-89.

20. See e.g. Colinvaux, "Donor Advised Funds", supra note 14 at 52-53; Mary C Hester, "Donor-Advised Funds: When Are They the Best Choice for Charitably Minded Clients?” (2008) 108:1 Journal of Taxation 330 at 334; Mark Gillen, Lionel Smith \& Donovan Waters, Waters' Law of Trusts in Canada, 4d (Toronto: Thomson Reuters, 2012) at 14; Income Tax Act, RSC 1985, c 1 (5th Supp), s 38 [ITA]. The contrasting treatment of public and private foundations is more marked in the United States.

21. Hester, ibid at 333.

22. IRC, supra note 4, $\$ \$ 4940,4942$. 
providers compared with a large number of private foundations. ${ }^{23}$

The stellar growth of DAFs indicates that these advantages are highly valued by donors. However, as noted above, that growth appears to far outpace the other potential advantage of DAFs - increasing overall levels of giving.

\section{Disadvantages}

The literature on DAFs highlights three key disadvantages: (1) delay in the distribution of assets to "doing" charities and in the achievement of public benefit; (2) reduced transparency and accountability; and (3) heightened potential for conflicts of interest.

\section{Delay}

A number of commentators and members of Parliament in Canada and the United States have noted concerns that there can be too much delay between the time when a donation is made to a DAF and the time when those donated funds are distributed to a charity to use in carrying out its purpose. ${ }^{24}$ Typically, this is on the basis that the recipient charity will use the funds to achieve public benefit, whereas the funds serve only a warehousing purpose in a DAF.

Delay is partially enabled by the lack of a clear minimum distribution rule for United States public charitable foundations and the application of a low, 3.5\%, minimum disbursement quota for all

23. Bjorklund, supra note 18 at 72 .

24. Catalyst for Change, supra note 4 at 110-11; Howard Husock, "Does Dave Camp Hate Mark Zuckerberg? The Surprising Attack On Donor Advised Funds" (28 March 2014), online: Forbes <www.forbes.com/sites/ howardhusock/2014/03/28/does-dave-camp-hate-mark-zuckerberg-thesurprising-attack-on-donor-advised-funds/\#315e8c6746b8>; Colinvaux, "Donor Advised Funds", supra note 14 at 67-71; Ray Madoff, "5 Myths About Payout Rules for Donor-Advised Funds" (13 January 2014), online (blog): The Chronicle of Philanthropy <www.philanthropy.com/article/5Myths-About-Payout-Rules-for/153809>; Brian Galle, "Pay it Forward? Law and the Problem of Restricted-Spending Philanthropy” (2016) 93:5 Washington University Law Review 1143 at 1198-1200. 
registered charities in Canada. ${ }^{25}$ United States public charities such as DAF providers are subject to an 'operational' test due to the wording of $I R C$ paragraphs 501(c)(3) and 170(c)(2)(B), which the Internal Revenue Service ("IRS") has interpreted for philanthropic intermediaries as requiring the organisation to distribute assets "commensurate with its financial resources". ${ }^{26}$ However, the application of this test depends very much on the circumstances and whether the charity has a good reason for retaining assets, and it appears that the IRS's main concern is with charitable assets being consumed in administrative expenses or otherwise used for a private purpose. ${ }^{27}$ This test is clearly quite woolly. Thus, while some commentators have suggested that it will require a certain degree of distributions from DAFs, ${ }^{28}$ given that the purpose of many DAF sponsors is to support charitable organisations by means of fundraising through the provision of flexible donor accounts, there seem to be good reasons for DAFs to distribute at the rate suggested by donors unless those rates are extremely slow or the fees charged are extremely high. ${ }^{29}$ Additionally, it appears that most large United States DAF providers have adopted model policies on 'timing, distributions and inactivity' based on

25. IRC, supra note $4, \$ 4942$. The United States imposes a 5\% distribution requirement on the net investment assets of most private foundations. In Canada, registered charities must expend or distribute $3.5 \%$ of their property (less some liabilities), but excluding property directly used in carrying on charitable activities or administration and with some ability to carry forwards and backwards credits for excess expenditure: see ITA, supra note 20, ss 149.1(2)(b), (3)(b), (4)(b).

26. US, Internal Revenue Service, Exempt Organizations Continuing Professional Education Technical Instruction Program for Fiscal Year 1989, Special Emphasis Program: Charitable Fund-raising (1989) at 13-6, online (pdf): IRS <www.irs.gov/pub/irs-tege/eotopicm89.pdf>.

27. Ibid at 14-5.

28. See e.g. Colinvaux, "Donor Advised Funds", supra note 14 at 63-64.

29. An analogy might be drawn here to United States "reasonableness" of accumulation cases, which consider when accumulation is "unreasonable, unnecessary and to the public injury": Ascher, Scott \& Fratcher, supra note 3 at $\$ 39.7 .9$. 
initial negotiations with the IRS. ${ }^{30}$ Nevertheless, individual DAFs are not subject to any hard disbursement rule. Thus while it appears that overall payout rates are far above these minima, ${ }^{31}$ there have been suggestions that a substantial minority of DAF accounts make no distributions at

30. Bjorklund, supra note 18 at 69-70. See also Hussey, supra note 4 at 7475 (noting that the required rate of distributions under some policies is miniscule).

31. National Philanthropic Trust, supra note 7 at 18. For instance, in the United States, the overall payout rate has been calculated as being above $20 \%$ for every year from 2013 to 2017 . The payout rate is calculated as distributions during the year, divided by assets at the start of the relevant year. This approach is preferred to other payout calculations as it more closely approximates the Canadian, United States and Australian approach of using the previous year's (or several years') assets to calculate the required distribution. In Canada, payout rates for DAF sponsors have been estimated at around $12 \%$ to $17 \%$ on average: Sjogren, supra note 8 at 91; Strategic Insight, "Donor-advised Funds: The Intersection of Philanthropy and Wealth Management" (2018) at 41, online (pdf): Investor Economics <www.investoreconomics.com/reports/donor-advisedfunds-the-intersection-of-philanthropy-and-wealth-management>. 
all for long periods. ${ }^{32}$ There is some empirical evidence to support this. ${ }^{33}$ There have also been suggestions that payout rates are dropping (and will continue to drop) as DAFs mature. ${ }^{34}$

Delay is also enabled in the United States by the use of DAFs as recipients of private foundation payouts, which satisfies the private foundation 5\% payout rule, but still leaves funds in an intermediary vehicle. ${ }^{35}$ Canadian private foundations may likewise meet their 3.5\% disbursement quota by distributing to DAFs, as DAFs should generally constitute 'qualified donees', and these arrangements would not typically fall foul of the non-arm's length inter-charity gift rules in section 188.1(12) of the ITA. ${ }^{36}$ Further, DAFs may distribute to other DAFs in the United

32. Philip Hackney \& Brian Mittendorf, "Donor-advised Funds: Charities with Benefits" (6 April 2017), online: The Conversation <theconversation. com/donor-advised-funds-charities-with-benefits-74516>; Sjogren, supra note 8 at 91 .

33. Paul Arnsberger, "Donor-Advised Funds: An Overview Using IRS Data" (Paper delivered at the Boston College Law School Forum on Philanthropy and the Public Good Conference on The Rise of DonorAdvised Funds: Should Congress Respond?, Washington, DC, 23 October 2015) 61 at 62, online: Digital Commons <lawdigitalcommons.bc.edu/ philanthropy-forum/donoradvised2015/papers/> (while Arnsberger's data includes a large number of very small DAFs, which may skew the results, it suggests that in the United States in 2012, around 22\% of DAF sponsors paid out no grants at all); Ellen Steele \& Eugene Steuerle "Discerning the True Policy Debate over Donor-Advised Funds" (October 2015) at 6-7, online (pdf): Urban Institute <www.urban.org/sites/default/ files/publication/72241/2000481-Discerning-the-True-Policy-Debateover-Donor-Advised-Funds.pdf> (citing a Vanguard Charitable employee that $30 \%$ of DAFs do not pay an amount out in a given year and a Silicon Valley Community Foundation employee that $4 \%$ of DAFs over USD $\$ 1$ million did not make a payout).

34. See e.g. Galle, supra note 24 at 1199.

35. The Economist, "Give and Take - A Philanthropic Boom: 'DonorAdvised Funds"' (23 March 2017), online: The Economist <www. economist.com/finance-and-economics/2017/03/23/a-philanthropicboom-donor-advised-funds $>$.

36. ITA, supra note 20. The provisions impose a penalty. Additionally, paragraph 149.1(4.1)(d) could be used to revoke charity status of the DAF recipient. 
States and Canada (satisfying the Canadian 3.5\% disbursement quota).$^{37}$ There are additional anti-avoidance rules in Canada that could be used to revoke charity status or impose administrative penalties where a charity has entered into a transaction (including a gift to another charity) "and it may reasonably be considered that a purpose of the transaction was to avoid or unduly delay the expenditure of amounts on charitable activities" ${ }^{38}$ Nevertheless, views expressed to the Special Senate Committee on the Charitable Sector indicate that such transfers occur. ${ }^{39}$ There is also evidence in the United States context to suggest that inter-DAF transfers are material. ${ }^{40}$

Delay also occurs in part due to conflicts of interest that are particularly pertinent for DAF providers linked to financial service providers, as discussed below.

37. In the Canadian context, see Canada, Senate, Special Committee on the Charitable Sector, Minutes of Proceedings, 42:1, No 6 (18 September 2018) at 102 (Kevin McCort, President and Chief Executive Officer, Vancouver Foundation), online (pdf): <sencanada.ca/Content/SEN/ Committee/421/cssb/pdf/06issue.pdf $>$ [McCort].

38. ITA, supra note 20, at ss 149.1(4.1)(a), 188.1(11). For a discussion of the provisions, see Theresa Man, "Disbursement Quota Reform: The Ins and Outs of What You Need to Know" (Paper delivered at the National Charity Law Symposium, Toronto, 6 May 2011) at 14-6, online (pdf): Canadian Bar Association <www.cba.org/cba/cle/PDF/CHAR11_Man_ Paper.pdf>.

39. McCort, supra note 37.

40. In the United States, see The Economist, supra note 35 (for the 2015 and 2016 years for several large DAFs, the first and third largest recipients of DAF distributions were DAFs); H Daniel Heist \& Danielle VanceMcMullen, "Understanding Donor-Advised Funds: How Grants Flow During Recessions" (2019) 48:5 Nonprofit and Voluntary Sector Quarterly 1066 at 1069, citing Giving USA, "Giving USA Special Report: The Data on Donor-Advised Funds - New Insights You Need to Know” (28 February 2018), online: Giving USA < givingusa.org/just-released-specialreport-the-data-on-donor-advised-funds-new-insights-you-need-toknow/s. 


\section{Conflicts of Interest}

Conflicts of interest have also been cited in relation to DAFs. As identified in Part II, DAF providers offer administration services to donors, for which they obtain a fee, which raises a potential conflict between the DAF provider's interests and those of the donor. In addition, a number of the largest DAF providers are linked to financial services firms that provide investment services, again for a fee. ${ }^{41}$ Desire to obtain fee income, including for affiliated entities, can result in conflict between the DAF provider's mission and duties and the interests of its for-profit affiliate. Often the fees are based on the amount of assets under investment, which can create a disincentive for the DAF provider to distribute too quickly. ${ }^{42}$ There are suggestions in the Fairbairn litigation that Fidelity Charitable's desire to increase the investment assets of its affiliated entity Fidelity Investments before the end of the financial year motivated the swift sale of Energous shares. ${ }^{43}$ There have also been suggestions that DAF providers adopt behavioural 'nudges' to influence donors to distribute less. ${ }^{44}$

While there is clearly potential for conflicts of interest for DAF providers in relation to their own administration service fees, a legal conflict is less clear cut for a DAF provider where its commercial affiliate earns investment fees. It is not clear that DAF providers, or their employees, will always have a financial interest in increasing its affiliate's fees. Nor would there necessarily be any duty owed to the commercial affiliate that would conflict with the DAF's duties to donors and to its

41. As to fees, see e.g. Hester, supra note 20 at 344 .

42. Compare Sjogren, supra note 8 at 81 ; Hussey, supra note 4 at 75 ;

Colinvaux, "Donor Advised Funds", supra note 14 at 57; The Economist, supra note 35.

43. Sullivan, supra note 9.

44. See e.g. Ann Charles Watts, "The Wolf in Charity's Clothing: Behavioural Economics and the Case for Donor-Advised Fund Reform" (2018) 43:3

University of Dayton Law Review 417 at 438-39. 
charitable purpose. ${ }^{45}$ Nevertheless, there may be an unwritten cultural and institutional bias for DAF sponsors established by a financial services firm to promote the interests of that firm. ${ }^{46}$

\section{Transparency and Accountability}

While private foundations must typically file separate returns with tax authorities detailing their major donors, assets and distributions, public charitable foundations do not. ${ }^{47}$ Instead they must identify assets and distributions at the DAF level, but only at the whole of foundation level, and do not have to publicly disclose donors. ${ }^{48}$ This minimal disclosure may hamper the formation of relationships that better inform donors about the effectiveness of their giving. ${ }^{49}$ Further, to the extent that private foundations funnel distributions to DAFs, they may be able to effectively avoid the accountability rules for private foundations that allow the public to determine the ultimate destination of donations. ${ }^{50}$

45. It is likely that DAF sponsors would not be required to use the investment services of their affiliate, as the IRS has applied Internal Revenue, 26 CFR subparagraphs 1.501(c)(3)-1(d)(1) (2001) [26 CFR] to preclude subparagraph 501(c)(3) status for charities that are required to use the services of a particular commercial entity: see Colinvaux, "Donor Advised Funds", supra note 14 at 66.

46. Compare Colinvaux, "Donor Advised Funds", ibid at 66.

47. Terry LaBant, "Charitable Giving: Beyond the Checkbook" (2018) 128:1 Journal of Taxation 36 at 38; Steele \& Steuerle, supra note 33 at 2.

48. Ibid.

49. Compare Watts, supra note 44 at 440-41.

50. See e.g. Roger Colinvaux, "Fixing Philanthropy: A Vision for Charitable Giving and Reform” (2019) 162:9 Tax Notes 1007 at 1011; Suzanne Goldenberg, "Secret Funding Helped Build Vast Network of Climate Denial Thinktanks" (15 February 2013), online: The Guardian <www. theguardian.com/environment/2013/feb/14/funding-climate-changedenial-thinktanks-network>. 


\section{The Australian Context}

The following section outlines the broad regulatory regime for Australian charities (Part III.A), as well as the more specific rules that apply to donation concessions for ancillary fund philanthropic intermediaries (Part III.B). Part III.C then identifies the way that DAFs arise in the Australian context as part of public ancillary funds and notes the contours of Australian DAFs.

\section{A. Regulation of the Charity Sector}

Unlike a number of other federations (such as the United States and Canada), Australia relies on a national charities commission rather than its federal tax authority to act as the principal regulator. Australia's first independent national charity-focused regulator (the Australian Charities and Not-for-profits Commission, or "ACNC") ${ }^{51}$ was created in 2012 and, at the same time, Australia adopted a comprehensive statutory definition of 'charity' at the federal, but not state, level. ${ }^{52}$ Becoming a registered charity with the ACNC is a necessary precondition to unlocking the various federal tax concessions, such as income tax exemption. ${ }^{53}$ Thus, the ACNC determines charity status and registers eligible entities; ${ }^{54}$ monitors and enforces registered charities' obligations; ${ }^{55}$ and maintains a public register containing information on registered charities. ${ }^{56}$ Registered charities are subject to regular financial and non-financial reporting, and the ACNC has significant additional information gathering and monitoring powers. ${ }^{57}$ Registered charities must also comply with governance standards that enshrine minimum outcomes in respect of the

51. Australian Charities and Not-for-profits Commission Act 2012 (Cth), 2012/168 [ACNC Act].

52. Charities Act 2013 (Cth), 2013/100 (Austl).

53. See, e.g. Income Tax Assessment Act 1997 (Cth), 1997/38 (Austl), s 50-5 [ITA 97].

54. ACNC Act, supra note 51, s 15-5(2), part 2-1.

55. Ibid, s 15-5(2)(b)(ii), ch 3-4.

56. Ibid, part 2-2.

57. Ibid, part 4-1, division 60 . 
practices and procedures adopted by an entity to govern its operations. ${ }^{58}$ Charities are also potentially subject at both the federal and state level to a range of additional regulators, including the federal Commissioner of Taxation..$^{59}$ However, prior to the introduction of the ACNC, there had been various concerns about the practical enforcement of charity controller duties by the relevant regulators. For instance, one concern was that the loss of tax concessions was frequently too punitive (and often harmful to potential benefit recipients) to be a realistic option for the Commissioner of Taxation and that the charity sector was not a high priority for the national corporate regulator given its many other responsibilities. ${ }^{60} \mathrm{~A}$ further concern was that state and territory attorneysgeneral and incorporated association regulators lacked sufficient resources and information to effectively pursue breaches and that court intervention, where required, imposed onerous procedural burdens. ${ }^{61}$

\section{B. Ancillary Funds}

In contrast to the situation in Canada and the United States, donation concessions do not generally follow charity status in Australia. Instead, the concessions are provided for various classes of entities or by way of specific listing in the legislation. Deductible gift recipient ("DGR") status means that donors can claim an income tax deduction for gifts

58. Australian Charities and Not-for-profits Commission Regulation 2013 (Cth), 2013/124, s 45.1.

59. Austl, Treasury, Scoping Study for a National Not-for-profit Regulator: Final Report (2011) at 63, online (pdf): Archive <web.archive.org/ web/20190522155200/archive.treasury.gov.au/documents/2054/ PDF/20110706\%20-\%20Final\%20Report\%20-\%20Scoping\%20Study. pdf $>$.

60. Ibid at 66; Ian Murray, "Fierce Extremes: Will Tax Endorsement Stymie More Nuanced Enforcement by the Australian Charities and Not-forprofits Commission?” (2013) 15:2 Journal of Australian Taxation 233 at 252-55.

61. Austl, Treasury, Scoping Study for a National Not-for-profit Regulator, Consultation Paper (2011) at 10-11, online (pdf): Australian Treasury $<$ www.treasury.gov.au/sites/default/files/2019-03/Scoping_Study_Report_ Consultation_Paper.pdf>. 
or contributions, provided certain other integrity criteria are satisfied. ${ }^{62}$ There is no cap on the amount of the deduction. Non-cash gifts can also be made and provided integrity rules are satisfied, and minimum value thresholds reached, the deduction is for the value of the property. ${ }^{63} \mathrm{~A}$ gift of property, such as shares, would typically cause unrealised capital gains to be brought to account, without any exemption. ${ }^{64}$

There are numerous DGR categories, grouped in overarching classifications, some of which are (1) health; (2) education; (3) research; and (4) welfare and rights. ${ }^{65}$ "Ancillary funds" are one class of DGR and are classified as either public or private ancillary funds. ${ }^{66}$ As purpose trusts, ${ }^{67}$ most public and private ancillary funds should be in the form of charitable trusts. The public/private distinction relates to the range of persons who may donate to and administer the trust, rather than the nature of those who benefit. ${ }^{68}$ Ancillary funds are thus philanthropic intermediaries that can receive tax deductible donations and then distribute them to other DGRs, but they are not permitted to distribute to other ancillary funds. ${ }^{69}$ However, if the Commissioner of Taxation approves, donors have the ability to port assets out of a private ancillary fund ("PAF") into the sub-fund of a public ancillary fund ("PuAF"), to port assets from one PuAF to another or to port assets out of a PuAF to

62. ITA 97, supra note 53, s 30-15(1).

63. Ibid.

64. The only gifts which result in both a deduction and a disregarding of unrealised capital gains are gifts of culturally significant items to Australian public galleries, museums and libraries: see ibid at s 30-15(1) items 4 and 5 shown in table, s 118-60(2). Testamentary bequests to DGRs do not generally qualify for a deduction, but can result in unrealised capital gains being disregarded, see s 118-60(1).

65. ITA 97, supra note 53, sub-division 30-B.

66. Ibid, s 30-15(1) item 2 shown in table.

67. Ibid, item 2 shown in table in s 30-15(1); Taxation Administration Act 1953 (Cth), 1953/1 (Austl), schedule 1, ss 426-102(1), 426-105(1).

68. Private Ancillary Fund Guidelines 2009 (Cth), 2009/1 (Austl), rules 14, 44-46 [PAFG 2009]; Public Ancillary Fund Guidelines 2011 (Cth), 2011/1 (Austl), rules 14, 44-45 [PAFG 2011].

69. ITA 97, supra note 53, s 30-15(1) item 2 shown in table. 
establish a PAF ${ }^{70}$ This may be to deal with generational change (so that PAF assets are then split into multiple smaller sub-funds for the next generation), or because the sub-fund has grown to the point that the administration costs of a PAF become less onerous. ${ }^{71}$ An express reason for portability was also so that an ancillary fund donor can switch to a different trust manager with lower fees. ${ }^{72}$

To meet the description of a PuAF or PAF, the trustees must have agreed to comply with the public or private ancillary fund guidelines. ${ }^{73}$ The guidelines are sets of regulations that impose a range of conditions, including that the ancillary fund must meet a minimum annual distribution requirement of $5 \%$ (for PAFs) or $4 \%$ (for PuAFs) of the market value of the fund's net assets as at the end of the preceding financial year. ${ }^{74}$

These minimum distribution rates were described, when first introduced in the context of PAFs, as "strik[ing] the right balance between ensuring resources flow to the charitable sector now, whilst also allowing PAFs to grow for the benefit of the sector in the future" ${ }^{75}$ The rules are thus premised on an understanding that the distribution

70. PAFG 2009, supra note 68, rule 51A; PAFG 2011, supra note 68, rule 50.

71. See e.g. David Ward, "Public Ancillary Funds (PuAF) Trustee Handbook" 2d (August 2016) at 18, online (pdf): Australian Philanthropic Services <australianphilanthropicservices.com.au/wp-content/uploads/2014/05/ PA-PuAF-Handbook-2016.pdf>.

72. Compare Austl, Commonwealth, Assistant Treasurer, Private Ancillary Fund and Public Ancillary Fund Amendment Guidelines 2016 (Explanatory Statement) (2016) at 4.

73. Taxation Administration Act 1953 (Cth), 1953/149 (Austl), vol 2, schedule 1, ss 426-102(1), 426-105(1).

74. PAFG 2009, supra note 68, rule 19; PAFG 2011, supra note 68, rule 19. Where the fund meets its expenses from its own assets or income, the minimum distribution is AUD $\$ 11,000$ or $5 \%$ (AUD $\$ 8,800$ or $4 \%$ : public ancillary funds), whichever is the greater.

75. Nick Sherry, Press Release of the Assistant Treasurer, No 6, "Important Philanthropic Reforms and Further Sector Consultation" (25 June 2009), online: Archive <web.archive.org/web/20091002174820/http:/ ministers.treasury.gov.au/DisplayDocs.aspx?doc=pressreleases/2009/006. htm\&pageID=003\&min=njsa\&Year=2009\&DocType $=0>$. 
of benefits between different generations is a relevant issue, while also enabling ancillary funds to endure.

A number of other rules in the guidelines may also help to address the potential for enhanced agency costs from the misapplication of funds, or mission drift. These include rules as to the trustees' degree of care, skill and diligence; ${ }^{76}$ the need for an (private), or a majority of the (public), individual(s) involved in decision making of the fund to be persons with a degree of responsibility to the community; $;^{77}$ exclusion from the control of a fund for persons convicted of indictable taxation offences; ${ }^{78}$ limits on indemnification of trustees; ${ }^{79}$ and disclosure of a range of related party transactions, along with restrictions on such transactions or related party benefits. ${ }^{80}$

In addition to the general reporting obligations for income tax exemption and charity registration, ancillary funds are also obliged to lodge annual information returns, including assets, liabilities, donations, income, expenses, and distributions. ${ }^{81}$ This is somewhat similar to the Form 990 information required of DAF sponsors in the United States ${ }^{82}$ and affords the Commissioner reasonable insight into ancillary fund accumulation. However, unlike the Form 990, Australian ancillary funds do not have to report on the number of DAF or sub-fund management accounts. ${ }^{83}$

Thus ancillary funds are analogous to charitable foundations in Canada, and PAFs play a similar role to private foundations in the United States context. PuAFs are frequently used to establish the Australian

76. PAFG 2009, supra note 68, rule 13; PAFG 2011, supra note 68, rule 13.

77. PAFG 2009, ibid, rule 14; PAFG 2011, ibid, rule 14.

78. PAFG 2009, ibid, rule 16; PAFG 2011, ibid, rule 16.

79. PAFG 2009, ibid, rule 18; PAFG 2011, ibid, rule 18.

80. PAFG 2009, ibid, rules 26.2, 41-2; PAFG 2011, ibid, rules 26.2, 41-2.

81. See e.g. Australian Taxation Office, "Ancillary Fund Return 2019" (July 2019), online (pdf): Australian Taxation Office <www.ato.gov.au/ assets/0/104/1909/2003/c35eab28-a707-47bd-a21c-c23d991027f0.pdf> [ATO, “Ancillary Fund Return 2019”].

82. Arnsberger, supra note 33 at 62; Heist \& Vance-McMullen, supra note 40 at 5-6.

83. ATO, “Ancillary Fund Return 2019”, supra note 81. 
equivalent of DAFs being 'sub-funds'. However, before discussing subfunds, it is important to put the size and growth of ancillary funds in context. Since their inception in 2001, the number of PAFs has grown fairly steadily each year to 1,426 as at 1 July 2016, holding assets of AUD $\$ 8.3$ billion and with grants for the preceding year of AUD $\$ 457$ million. ${ }^{84}$ The number of PuAFs has remained relatively constant at 1,449 as of 1 July 2016, holding AUD \$3.8 billion in assets and with grants for the preceding year of AUD $\$ 394$ million. ${ }^{85}$ It is clear that both the number of ancillary funds and the amounts held are much lower than in the United States. Nevertheless, despite being subject to minimum annual distribution requirements, PuAFs and PAFs have, in general, been building their net assets from additional donations and retained earnings ${ }^{86}$ A proposal in 2015 to reduce the minimum distribution requirements for ancillary funds resulted in angst about whether this would permit inappropriate retention of assets by ancillary funds, ${ }^{87}$ and about whether the minimum distribution rate should instead be increased. ${ }^{88}$

84. Australian Taxation Office, "Taxation Statistics 2015-16" (19 April 2018), online: Australian Government <data.gov.au/data/dataset/ taxation-statistics-2015-16/resource/6a9547fc-2217-4f0b-a4035117909f9ebb?inner_span=True> [ATO, "Taxation Statistics"].

85. Ibid.

86. Ibid; John McLeod, "The Support Report: The Changing Shape of Giving and the Significant Implications for Recipients" (June 2018) at 17-9, online (pdf): JB Were <www.jbwere.com.au/content/dam/jbwere/ documents/JBWere-Support-Report-2018.pdf>.

87. Philanthropy Australia, "Philanthropy Australia Submission — Exposure draft of amendments to the Private Ancillary Fund Guidelines 2009 and the Public Ancillary Fund Guidelines 2011" (12 February 2016) at 4, online (pdf): Australian Treasury <treasury.gov.au/sites/default/ files/2019-03/T289758-Philanthropy_Australia.pdf>.

88. See e.g. Community Council of Australia, "Private Ancillary Fund (PAF) and Public Ancillary Fund (PuAF) Amendment Guidelines 2015" (February 2016), online: Community Council for Australia <www. communitycouncil.com.au/content/private-ancillary-fund-paf-andpublic-ancillary-fund-puaf-amendment-guidelines-2015>. 


\section{DAFs or "Sub-funds"}

In the Australian context, DAFs are typically created as management accounts, called 'sub-funds', within a public ancillary fund. ${ }^{89}$ Those public ancillary funds are often community foundations, affiliates of trustee or financial services entities, or form part of the fundraising component of more directly active charities such as universities. ${ }^{90}$ The primary advantage is generally the reduced administration requirements and costs of a sub-fund within a PuAF compared with establishing and operating the donor's own PAF. The income tax donation distinctions are not as marked as in North America, although PuAFs are subject to a marginally lower required minimum distribution rate (discussed in Part III.B), which may make them slightly more attractive than PAFs. However, as in North America, establishing a sub-fund within a PuAF involves the donor ceding control and retaining only advisory rights. ${ }^{11}$

There is virtually no public reporting on Australian sub-funds, and the private and public reporting to and by the Australian Taxation Office and the ACNC noted in Part III.B does not require any identification of sub-funds. A survey of large Australian sub-fund providers nevertheless indicates that, based on their 2017-18 data, there are over 1,995 Australian sub-funds with assets of AUD \$1 billion and which made distributions that year of AUD $\$ 57$ million. ${ }^{92}$ While the eight-fold size differential between sub-funds and PAFs mirrors that in the United States, the number of Australian sub-funds and PAFs are relatively equal, which differs from the large number of United States DAFs. The absolute numbers are also relatively small in Australia.

89. McLeod, supra note 86 at 19; Krystian Seibert, "Snapshot of Sub-funds in Australia: CSI Swinburne Research Brief” (March 2019) at 1, online (pdf): Centre for Social Impact Swinburne <researchbank.swinburne. edu.au/file/68f5d8fa-1441-42b6-b73d-939e70a2e354/1/2019-seibertsnapshot_of_sub-funds.pdf>.

90. McLeod, supra note 86 at 19.

91. Seibert, supra note 89 at 1 . See also Australian Taxation Office, Taxation Determination TD 2004/23.

92. Seibert, ibid. 


\section{Aspects of the Australian Rules that May Help Address DAF Problems}

The Australian regulation of philanthropic intermediaries provides useful ideas for dealing with the issues of deferred distributions/public benefit and conflicts of interest. However, when it comes to transparency and accountability, the United States rules seem more demanding than those in Australia. While this is an important area, especially to the extent that it bolsters market mechanisms for controlling conflicts of interest, the Australian approach does not seem particularly informative for North American readers and so is not explored further.

\section{A. Dealing with Delay in Distributions/Public Benefit}

\section{Minimum Distribution Requirements}

There have been calls, including initially by the United States Treasury, for DAF sponsors to be subject to a $5 \%$ minimum distribution rule akin to that for private foundations, whether applied generally or only to DAF assets. ${ }^{93}$ Canada already has a lower 3.5\% disbursement quota. However, the United States Treasury's 2011 report into DAFs noted divergent views on payout rules and indicated that it was premature to make any recommendation. ${ }^{94}$ Commentators have more recently tended to focus on a timeframe within which a DAF provider must distribute each donation to a DAF. For instance, a five to ten year window, so as to provide a temporal link to the original donation, but also sufficiently

93. US, Treasury, General Explanations of the Administration's Fiscal Year 2001 Revenue Proposals (February 2000) at 106-07, online (pdf): United States Treasury <www.treasury.gov/resource-center/tax-policy/Documents/ General-Explanations-FY2001.pdf> [US Treasury, General Explanations].

94. US, Treasury, Report to Congress on Supporting Organizations and Donor Advised Funds (December 2011) at 81-82, online (pdf): United States Treasury <www.treasury.gov/resource-center/tax-policy/Documents/ Report-Donor-Advised-Funds-2011.pdfs. 
long to avoid disincentivising donors. ${ }^{95}$ Analogously, it appears that the United States Treasury and the IRS are now considering whether distributions by private foundations to DAFs should be subject to time limits on further DAF distributions. ${ }^{96}$ The chief reasons for this change of emphasis appear to be concerns that a $5 \%$ rate may act to reduce overall distribution levels and that it may also allow DAFs to last indefinitely. A focus on contributions potentially fits with Heist and Vance-McMullen's DAF empirical analysis which demonstrates that DAF distributions are influenced not just by the quantum of assets, but also by the level of annual contributions. ${ }^{97}$

Several commentators have also argued the relevant payout rule should apply at the individual DAF account level since it is the low distributing DAFs that present problems. ${ }^{98}$ Tracking individual accounts, especially tracking timeframes for contributions, would add administration costs, detracting from a key advantage of DAFs. ${ }^{99}$

What guidance can be obtained from Australia? A 4\% minimum distribution rate was imposed on PuAFs in 2012 along with a one-year transition period. ${ }^{100}$ Prior to this, the Australian Taxation Office applied a much more vague test under the income tax endorsement provisions that required a charitable fund to be "applied for the purpose for which it was established", ${ }^{101}$ which the Taxation Office interpreted to require some

95. Colinvaux, "Donor Advised Funds", supra note 14 at 67-68. Madoff has suggested a seven-year payout period: supra note 24 . See also, Hussey's individual retirement account approach: supra note 4 at 88-91.

96. US, Internal Revenue Service, Request for Comments on Application of Excise Taxes With Respect to Donor Advised Funds in Certain Situations, Notice 2017-73 (18 December 2017), online (pdf): Internal Revenue Services <www.irs.gov/pub/irs-drop/n-17-73.pdf>.

97. Heist \& Vance-McMullen, supra note 40 at 19.

98. Hussey, supra note 4 at 90-91; Colinvaux, "Donor Advised Funds", supra note 14 at 68-69.

99. See e.g. James A Borrasso, “Opening the Floodgates: Providing Liquidity to the Charitable Marketplace through Changes to Donor-Advised Funds" (2018) 18:4 University of Illinois Law Review 1533 at 1563-64.

100. PAFG 2011, supra note 68 , rule 52.

101. ITA 97, supra note 53, s 50-60 (now repealed). 
distributions, with the level depending on the circumstances. ${ }^{102}$ Like the United States operational test, this meant a fairly flexible framework for PuAFs. While there are no figures for earlier years, ${ }^{103}$ as a percentage of total assets at the start of the financial year, PuAF payout rates have gradually declined between 2012 and 2016 from 22\% to $11 \% .{ }^{104}$ Despite this downward trend and although the underlying data has not been publicly released, it appears that average distribution rates for PuAFs remain closer to the $22 \%$ mark. ${ }^{105}$ At the same time, the number of PuAFs has remained almost constant, while assets have more than doubled from AUD \$1.7 billion to AUD \$3.8 billion. ${ }^{106}$ While the reduction in the distribution rate may thus partly reflect increased donations into ancillary funds - due to greater certainty following the implementation of the guidelines - it is lower than the overall payout rate for DAFs in the United States and suggests some caution in implementing a low payout rate. Nevertheless, payouts are significantly higher than the minimum distribution rate of $4 \%$. It also appears that a number of PuAFs have been applying the minimum distribution requirements to each sub-fund (or DAF) that they manage. ${ }^{107}$ Further, despite concerns about added complexity, it does not seem that a minimum distribution requirement

102. For a discussion of the Australian Taxation Office's approach, see Ian Murray, "Charity Accumulation: Interrogating the Conventional View on Tax Restraints" (2015) 37:4 Sydney Law Review 541 [Murray, "Charity Accumulation"].

103. Public ancillary fund data was not collected before 2012 .

104. These number are based on distributions divided by assets at the start of the financial year. The figures are derived from ATO, "Taxation Statistics", supra note 84.

105. Letter from the Prime Minister's Community Business Partnership to the Treasury on the Exposure Draft of Amendments to the Private Ancillary Fund Guidelines 2009 and the Public Ancillary Fund Guidelines 2011 (12 February 2016) at 3-4, online (pdf): Community Business Partnership <www.communitybusinesspartnership.gov.au/wp-content/ uploads/2017/06/signed_paf_puaf_submission_to_treasury_-_feb_2016. pdf $>$, referring to data privately provided by the Australian Taxation Office.

106. The figures are derived from ATO, "Taxation Statistics", supra note 84.

107. See e.g. Ward, supra note 71 at 10. 
has dampened enthusiasm for PuAFs. Indeed, as noted above, a number of PuAFs are voluntarily tracking the distribution requirement at the sub-fund level. This may be because sub-funds are internally tracked in any event as separate management accounts, so that it is quite easy to calculate a payout rate. If the payout rate was set higher (than $4 \%$ or 5\%) such that it exceeded expected investment earnings after taking account of inflation, likely around $10 \%,{ }^{108}$ then complexity would not be increased, but the payout would start to resemble a rule that required contributions to be spent within a certain timeframe.

The risk with too high a payout rate is that it may reduce overall donations to charities if DAF donations are not replaced by other charitable donations. One way to view this risk is by comparing the cost of the tax benefit obtained by donors with the extra giving achieved by DAFs, which may be lost. Due to the non-cash donation rules in the United States (and non-taxation of unrealised capital gains when assets are given to a DAF), ${ }^{109}$ this cost may come close to the full value of the donated assets multiplied by the donor's marginal income tax rate plus that value multiplied by the top capital gains tax rate. Similarly, in Canada, donors can potentially obtain a tax credit for donations to DAFs and some non-cash assets (like publicly listed shares) are exempt from capital gains tax on donation. The Special Senate Committee on the Charitable Sector has recommended testing a capital gains tax exemption for donations of private company shares. ${ }^{110}$

108. Galle, supra note 24 at 1187-90. Several United States studies of foundation returns suggest that the mean (not the median) return after inflation is around $9 \%$ to $11 \%$.

109. James Andreoni, "The Benefits and Costs of Donor-Advised Funds" (2018) 32:1 Tax Policy and the Economy 1 at 25. Andreoni discusses the likely percentage of the value of non-cash assets that an unrealised gain comprises, noting that it may not be unreasonable to assume that many DAF donors have an $85 \%$ unrealised gain. As to non-cash donation deductions, see e.g. Roger Colinvaux \& Harvey P Dale, "The Charitable Contributions Deduction: Federal Tax Rules" (2015) 68:2 Tax Law 331 at 341-46; Colinvaux, "Donor Advised Funds", supra note 14 at 72-75.

110. Catalyst for Change, supra note 4 at 101-08. 
Account must also be taken of the time to distribute the DAF funds (potentially with a lower return on investment than if the money had been put to use by a charity, reflecting an opportunity cost ${ }^{111}$ and less the not inconsiderable transaction costs of accepting non-cash assets. ${ }^{112}$ Nevertheless, as top marginal tax rates/the highest level of tax credits, plus capital gains tax rates are still less than $100 \%$ and as the average deferral is around four years, ${ }^{113}$ this cost should typically be less than the benefit of the additional giving. However, that is only where all DAF giving is new giving. Andreoni has conducted cost-benefit analysis in the United States to calculate that if the average DAF donor saves close to top marginal rates on DAF donations and that the return on investment in DAFs is marginally smaller than for direct giving to charities, then around $30-40 \%$ of all giving to DAFs would need to be additional giving in order for the benefits to exceed the costs. ${ }^{114}$ Given the large increase in giving to DAFs in the United States, coupled with fairly flat overall rates of giving, ${ }^{115}$ this seems unlikely. The lower base of charity assets in Canada makes increased giving more likely, although a rate of $30-40 \%$ is very high.

Thus, while there should be some concern about reduced giving, we should also look very closely at the advantages and disadvantages of the temporal substitution effected by DAFs. That is, substituting funding for today's generation with funding for a future generation. Further guidance on this issue can be obtained from discussions in Australia

111. Compare Andreoni, supra note 109 at 18-19, 22-23.

112. Colinvaux, "Donor Advised Funds", supra note 14 at 75-81. Colinvaux discusses the transaction costs of non-cash donations, noting that financial service firm-linked DAF sponsors may actually be well placed to reduce these costs compared with other charities.

113. See, e.g. Andreoni, supra note 109 at 27-30.

114. Ibid at 33 .

115. Compare Colinvaux, "Donor Advised Funds", supra note 14 at 60. Andreoni, supra note 109 at 38-39, has also examined the effect of 2013 tax rate changes in the United States on DAF giving to conclude that DAFs are not causing material increases in giving. 
about accumulation by charities. ${ }^{116}$ Those discussions suggest that, while accumulation can produce additional public benefit through enhancing the sustainability of services, pluralism and efficiency, ${ }^{117}$ it is inherent in the notion of accumulation that the delivery of some benefits will be deferred. Further, an emphasis on the sustainability and longevity of the charity itself may be matched by too little regard for potential benefit recipients in the current generation or for efficiency in distributing benefits. This is a particular problem for philanthropic intermediaries as the benefits arising from accumulation are largely premised on an accumulating charity using some of its assets for activities or distributions other than accumulation. A significant build-up of assets in a small number of intermediaries, which reflects the more mature DAF sector in the United States, is likely to displace assets from those other charities and thus reduce their financial resilience because their ability to plan for the

116. See especially Ian Murray, "Nudging Charities to Balance the Needs of the Present Against Those of the Future" in Ron Levy et al, eds, New Directions for Law in Australia (Canberra: ANU Press, 2017) 347; Murray, "Charity Accumulation", supra note 102; Ian Murray, "Accumulation by Charities: Do Australian Legal Restraints Maintain an Intergenerational Balance?" (PhD Dissertation delivered at the University of Tasmania, 2018 - forthcoming in 2020 as a monograph with Cambridge University Press) [Murray, "Intergenerational Balance"]; Fiona Martin, "'To Be, or Not to Be, a Charity?' That is the Question for Prescribed Bodies Corporate Under the Native Title Act" (2016) 21:1 Deakin Law Review 25 at 38-40; Michael Booth et al, "Financial Reserves: A Necessary Condition for Not-for-profit Sustainability?” in Zahirul Hoque \& Lee Parker, eds, Performance Management in Nonprofit Organizations (New York: Routledge, 2014) 109; Austl, Treasury, Consultation Paper: Native Title, Indigenous Economic Development and Tax (October 2010) at 6, online (pdf): Treasury < treasury.gov.au/sites/default/files/2019-03/ CP_Native_Title_IED_and_Tax.pdf $>$.

117. Pluralism being a state of affairs in which decision-making authority and power are distributed amongst various groups and which is perceived as enhancing autonomy and innovation. See Robert Dahl, Dilemmas of Pluralist Democracy: Autonomy vs. Control (New Haven: Yale University Press, 1982); Nicholas Miller, "Pluralism and Social Choice" in Robert Dahl, Ian Shapiro \& José Antonio Cheibub, eds, The Democracy Sourcebook (Cambridge: MIT Press, 2003) 133 at 140. 
future and deal with contingencies is reduced by having less control over when and whether funds will be received from DAFs. ${ }^{118}$ Intermediaries also heighten the risk of another set of agency costs, ${ }^{119}$ including a desire to amass assets to enhance their social status, raising the risk of a loss of focus on a charity's purpose, or 'mission drift'; or, as discussed in Part II.C.2, to maintain fee levels. ${ }^{120}$

The benefits and detriments of accumulating assets raise issues of fairness between different generations and efficiency as to the distribution of any net (public) benefit. Accumulation thus raises a social concern that a charity is achieving insufficient public benefit for the present generation. ${ }^{121}$ 'Intergenerational justice' is a potential normative basis for answering how that balance should be set between public benefit for now and public benefit for the future, in order to maintain social cohesion.

118. Compare Cloutier, supra note 18 at 99.

119. Agency costs arise from the inevitable divergence between the interests of a principal and a person to whom the principal delegates some decisionmaking authority. See Michael Jensen \& William Meckling, "Theory of the Firm: Managerial Behaviour, Agency Costs and Ownership Structure" (1976) 3:3 Journal of Financial Economics 305 at 308-09. In the charity context, see e.g. Geoffrey Manne, "Agency Costs and the Oversight of Charitable Organizations" (1999) 2:1 Wisconsin Law Review 227 at 234-35; Oliver Williamson, "Organization Form, Residual Claimants and Corporate Control” (1983) 26:2 The Journal of Law and Economics 351 at 358-59.

120. As to the agency costs imposed by DAFs, see Galle, supra note 24 at 1162-66.

121. See e.g. The Law Commission, "The Rules against Perpetuities and Excessive Accumulations" (31 March 1998) at 10.19, online (pdf): Law Commission <www.lawcom.gov.uk/app/uploads/2015/03/lc251_The_ Rules_Against_Perpetuities_and_Accumulations.pdf>; Michael Klausner, "When Time Isn't Money: Foundation Payout Rates and the Time Value of Money" (2003) 1:1 Stanford Social Innovation Review 51. Compare Evelyn Brody, "Charitable Endowments and the Democratization of Dynasty” (1997) 39:3 Arizona Law Review 873 at 928-39. 
Intergenerational justice is not Hansmann's 'intergenerational equity'. ${ }^{122}$ It refers to normative theories about the obligations that are owed by the present generation in relation to people in the past and the future. While the content and concept of intergenerational justice remain debated, it is often applied to theories that employ political, philosophical concepts of 'justice' to relations between non-contemporaneous persons. ${ }^{123}$ Justice has various dimensions, including 'distributive justice', which concerns the basis upon which and methods by which benefits and costs ought to be allocated amongst members of society. ${ }^{124}$ Intergenerational justice may, therefore, mean that the current generation owes a duty to redistribute resources to persons intergenerationally, based on the degree to which this would satisfy their fundamental social and economic needs. ${ }^{125}$ Of course, this depends on the resources likely to be available to future generations. So, intergenerational justice might require a charity to subsidise current benefit recipients by borrowing or distributing heavily to fund the current provision of services. Alternatively, a charity might increase resources available for future benefit recipients by accumulating the majority of its resources as investments or constructing long-lasting facilities.

122. Henry Hansmann, "Why do Universities Have Endowments?" (1990) 19:1 Journal of Legal Studies 3 at 14. Hansmann's treatment of intergenerational equity has dissuaded some recent writers from exploring the relevance of intergenerational justice to charity accumulation more broadly: see e.g. Booth et al, supra note 116 at 116-7.

123. Axel Gosseries \& Lukas Meyer, eds, Intergenerational Justice (New York: Oxford University Press, 2009); Joerg Tremmel, ed, Handbook of Intergenerational Justice (Cheltenham: Edward Elgar, 2006).

124. See generally, John Rawls, $A$ Theory of Justice: Revised Edition (Cambridge: Harvard University Press, 1999) at 52-58, 78-81; Gary A. Cohen, "Where the Action Is: On the Site of Distributive Justice" (1997) 26:1 Philosophy \& Public Affairs 3 at 3, 12-13.

125. See e.g. Frederic Gaspart \& Axel Gosseries, "Are Generational Savings Unjust?" (2007) 6:2 Politics, Philosophy and Economics 193 at 201-04, 209, 211-12; Dieter Birnbacher, "Responsibility for Future Generations" in Joerg Tremmel, ed, Handbook of Intergenerational Justice (Cheltenham: Edward Elgar, 2006) 23 at 34. 
Taking one interpretation of intergenerational justice as an example, 'sufficientarian' principles, such as Rawls' just savings principle, ${ }^{126}$ could be used to allocate costs and benefits. ${ }^{127}$ Intergenerational justice, through a sufficientarian lens, has been interpreted as requiring that the current generation avoid the pursuit of benefits that would impose costs on future generations, where to do so would result in the world being handed on in a lesser state to future generations, or in a state that fails to meet 'sufficientarian' standards for members of future generations. ${ }^{128}$ The benefit of this approach is that it can preclude the argument that current generations should materially sacrifice their own wellbeing to benefit larger (and likely better-off) future generations. ${ }^{29}$ If an absolute priority is afforded to those below the threshold, sufficientarianism may approve a small increase in well-being for more disadvantaged members of the present generation, rather than a very large increase for only marginally-less disadvantaged members of future generations who are above the threshold. ${ }^{130}$ That future generations may miss out in this

126. Rawls conceived of intergenerational savings obligations to preserve capital so as to enable the establishment and then maintenance of just institutions ("just savings" principle) as a substitute for and constraint on (rather than application of) distributive justice principles: see Rawls, supra note 124 at $251-58$.

127. As to 'sufficientarianism' or 'sufficiency', see Roger Crisp, "Equality, Priority and Compassion" (2003) 113:4 Ethics 745 at 752, 755762; George Sher, Equality for Inegalitarians (Cambridge: Cambridge University Press, 2014) ch 8-9.

128. See e.g. Lukas Meyer, "Intergenerational Justice" in Edward Zalta, ed, Stanford Encyclopedia of Philosophy (Summer 2016 Edition) online: Stanford Encyclopedia of Philosophy < plato.stanford.edu/archives/sum2016/ entries/justice-intergenerational/> [Meyer, "International Justice"]; Peter Laslett, "Is There a Generational Contract?" in Peter Laslett \& James Fishkin, eds, Philosophy, Politics, and Society, vol 6: Justice Between Age Groups and Generations (New Haven: Yale University Press, 1992) 24 at 29-30, 44-45.

129. If an absolute priority is given to people below the threshold. See e.g. Meyer, "International Justice", ibid.

130. Lukas Meyer \& Dominic Roser, "Enough for the Future" in Axel Gosseries \& Lukas Meyer, eds, Intergenerational Justice (New York: Oxford University Press, 2009) 219 at 222-25. 
way is less troubling if the threshold is low and relates to fundamental needs. ${ }^{131}$ A sufficientarian approach also forestalls the assertion that future generations must level themselves down to the position of earlier generations since the sufficientarian standard simply sets a minimum. Sufficientarianism might oblige a DAF intended to support educational charities to distribute heavily to universities to ensure (by way of scholarships and other processes) that particularly disadvantaged students are able to access educational opportunities, but only in such a way that the DAF, or other DAFs or charities, can continue to fund educational opportunities to students from future generations.

If intergenerational justice is conceived in terms of Rawlsian notions of justice, intergenerational justice rules ought primarily to be reflected in society's basic structure or institutions. ${ }^{132}$ Mandatory payout rates or timeframes are one way to achieve this. However, such payout rules do not do a very good job of reflecting the full range of principles of intergenerational justice. For instance, 'prioritarian' approaches, which prioritise the most disadvantaged first (in whatever generation they are born), ${ }^{133}$ might — with a reasonably strong priority and expectations that future generations will, on the whole, be better off — require distribution rates set at or close to $100 \%$ for new charities and at generational neutrality levels for pre-existing charities. ${ }^{134}$ Further, if flexibility is a DAF benefit worth saving because it supports pluralism or permits a sufficientarian standard to change over time as needs vary, it is likely to be difficult to set a rate that permits flexibility yet still precludes material accumulation.

131. Yitzhak Benbaji, "Sufficiency or Priority” (2006) 14:3 European Journal of Philosophy 327 at 338-42.

132. Compare John Rawls, Justice as Fairness: A Restatement (Cambridge: Harvard University Press, 2001) at 10-12. The "basic structure" is the way the "main political and social institutions of society fit together into one system of social cooperation, and the way they assign basic rights and duties and regulate the division of advantages that arises from social cooperation over time". This would include not only a political society's constitution but also broad structures such as "the structure of the economy" and "the family in some form".

133. See e.g. Meyer \& Roser, supra note 130 at 234-35.

134. Gaspart \& Gosseries, supra note 125 at 203-04, 209, 211-12. 
Certainly, the current rates ranging from $3.5 \%$ to $5 \%$ do not seem to be stopping a large build-up of assets.

Another method may be to shape charity or tax law (part of society's basic structure) to ensure that DAF directors and trustees consider issues of intergenerational justice, as reasonably understood by them, when making accumulation and spending decisions - and that the requirement to consider intergenerational justice is also imposed on DAF donors. ${ }^{135}$ The approach is consistent with charity independence and pluralism. However, it is not intended to give DAF controllers and DAF donors a blank slate to adopt any approach to accumulation that they wish or to simply ignore the issue. To do so would undermine the objective of producing public benefit in a fair and efficient manner. Rather, DAF directors and trustees could be expected to give genuine consideration to intergenerational issues and to act accordingly, including by requiring a degree of consideration by DAF donors and a response by the DAF provider if DAF donors do not consider the requirements of intergenerational justice.

This approach could be grafted onto existing fiduciary and statutory duties that already apply to charity directors and trustees. For instance, when complying with their duty to act with genuine consideration when exercising discretionary powers, ${ }^{136}$ DAF decision-makers (and advisers to the decision-makers, being the DAF donors) could be obliged to give genuine consideration to principles of intergenerational justice and to have regard to intergenerational justice in acting impartially as between potential benefit recipients. Given the potential alignment of DAF and donor interests in accumulating assets, key concerns with this approach are accountability and enforcement. Accountability might require the formulation of an accumulation/reserves policy at the DAF provider and DAF account level, including an explanation as to why levels of reserves

135. For a more detailed discussion, see Murray, "Intergenerational Balance", supra note 116.

136. In an Australian context, see Lutheran Church of Australia (South Australia District) Inc v Farmers' Co-operative Executors and Trustees Ltd, (1970) 121 CLR 628 (HCA) at 639, 652-53, per Barwick CJ and Windeyer J respectively. 
are held and the amount, purpose and proposed time of expenditure for any earmarked funds; and reporting against compliance by the DAF provider with the accumulation/reserves policy. ${ }^{137}$ Enforcement would require an effective regulator or regulators. Concerns about effective regulation of the charity sector and of conflicts of interest in the United States (see Part IV.B) may therefore make a payout rule a better option. Regulation in Canada seems more effective and may become even more so as a result of the recommendations of the Special Senate Committee on the Charitable Sector. Therefore, Canada may have more scope to implement duties to consider intergenerational justice. However, even there, a high minimum payout could potentially be offered as a safeharbour alternative to minimise increased administration costs.

\section{No Circular Distributions to Other Philanthropic Intermediaries}

As outlined in Part III.B, Australia prohibits any distributions from a private or public ancillary fund to another ancillary fund. Distributions must be made to other classes of (largely) non-intermediary deductible gift recipients. The one exception is portability of all the assets of an ancillary fund to another ancillary fund, with the approval of the Commissioner of Taxation. Portability does not remove the obligation to distribute the minimum percentage in the year that porting occurs. ${ }^{138}$ Given the Commissioner of Taxation's involvement in portability, these rules are relatively effective at ensuring that philanthropic intermediaries cannot keep circulating assets without distributing to non-intermediaries. They

137. Compare the requirement for reserves policies and reporting on those policies, at the whole of charity level, in Australia and in England and Wales: ACNC, "Charity Reserves: Financial Stability and Sustainability" (December 2016) at 5-7, online: $A C N C$ <www.acnc.gov.au/ACNC/FTS/ Charity_reserves.aspx $>$; Charity Commission for England and Wales, "Charity Reserves: Guidance CC19" (January 2016) at 9-10, online (pdf): Charity Commission for England and Wales <assets.publishing. service.gov.uk/government/uploads/system/uploads/attachment_data/ file/743078/CC19_sep18.pdf>; Charities (Accounts and Reports) Regulations (UK), SI 2008/629, s 40(3)(p).

138. PAFG 2009, supra note 68, rule 51A; PAFG 2011, supra note 68, rule 50. 
do, however, permit some flexibility to deal with changed circumstances and to bolster market mechanisms that operate to reduce conflicts of interest.

The Canadian anti-avoidance rules also serve this purpose to an extent, ${ }^{139}$ but they are vague, which is likely to make their behavioural impact uncertain. In particular, it is unclear what length of time constitutes an undue delay. Is a one or two-year delay acceptable? They may also apply in some change of circumstance situations such as moving assets from a private foundation to a public foundation DAF due to family changes or where a DAF donor believes enough has been accumulated to warrant the extra administrative costs of a private foundation. ${ }^{140}$ The United States has started the journey to dealing with circular distributions by imposing excise taxes, under the Pension Protection Act $2006^{141}$ reforms, on a range of distributions, but with an express savings for distributions to another public charity, thus potentially preventing distributions back to private foundations. ${ }^{142}$ However, at least one writer has suggested that the wording of the amendments still permits DAFs to make distributions to private foundations provided that the distribution is for a charitable purpose (i.e. a purpose specified in $I R C$ section $170(\mathrm{c})(2)(\mathrm{B}))^{143}$ and the DAF sponsor exercises expenditure responsibility (i.e. oversight). ${ }^{144}$ It clearly remains possible to distribute to another DAF provider. Indeed, $I R C$ section 4966 is worded so as to permit a "distribution" from a DAF account within a DAF provider to another DAF account within the same provider. ${ }^{145}$

139. As discussed in Part II.C.1, nn 36-38.

140. For a general discussion, see Man, supra note 38 at 23-25.

141. Pension Protection Act of 2006, 120 Stat 780 (US).

142. IRC, supra note $4, \$ 4966$. The express exceptions for distributions to DAFs and to the DAF sponsor organization of the relevant DAF are contained in $I R C$ paragraph 4966(c)(2).

143. Ibid, $\$ 170(\mathrm{c})(2)(\mathrm{B})$.

144. Hester, supra note 20 at 334.

145. See also ibid. 
Canada currently defines "charitable foundations" (public and private) and "charitable organizations" as categories of qualified donees. ${ }^{146}$ The United States defines "private foundations", 147 "donor advised funds" 148 and DAF "sponsoring organizations". ${ }^{149}$ It should, therefore, be relatively easy for Canada and the United States to prohibit transfers between foundations as Australia does. If Canada removes the foundation/organization distinction as recommended by the Special Senate Committee on the Charitable Sector, ${ }^{150}$ an approach analogous to that in the United States could still be adopted. The United States attempts to isolate charities that are primarily philanthropic intermediaries in its definition of private foundation. While the United States' definition of a DAF sponsor is broader, even that definition could be tightened to target organisations that primarily sponsor DAFs, rather than universities and other charities that provide DAFs as a sideline. ${ }^{151}$ That position would be closer to Australia, since ancillary funds cover only charitable foundations that are intended to be philanthropic intermediaries.

One learning from Australia is that there should be some ability to switch DAF providers and between public and private foundation status in support of market mechanisms or if circumstances change, provided this is subject to regulatory oversight. Australian experience also suggests that an absolute prohibition on grants to individuals or to other intermediaries can cause problems for DAFs wishing to make grants in relation to rural, regional and remote areas where there are not many eligible recipients. This has been a particular problem for

146. ITA, supra note 20, s 149.1(1).

147. IRC, supra note $4, \$ 509$ (a).

148. Ibid, $\$ 4966(\mathrm{~d})(2)$.

149. Ibid, $\$ 4966(\mathrm{~d})(1)$.

150. Catalyst for Change, supra note 4 at 84 .

151. See e.g. US Treasury, General Explanations, supra note 93. 
Australian community foundations, many of which operate PuAFs. ${ }^{152}$ In some instances, community foundations have had trouble finding DGR recipients, especially since many charities are not DGRs. ${ }^{153}$ This problem is likely to be less pressing in Canada and the United States where most charities are eligible recipients. However, some consideration may need to be given to whether grants to individuals should be permitted in rural, regional and remote areas. Further, in some rural, regional and remote areas, community foundations (which may have significant local knowledge) are the main charity. If the community foundation cannot accept distributions from a private foundation, then this limits the level of charitable activities that can be carried out in that community. ${ }^{154}$ This issue is likely to apply in the United States and Canada, and so thought should be given to whether distributions should be permitted to community foundations which have a purpose primarily linked to a rural, regional or remote geographic location. This would be consistent with the Special Senate Committee on the Charitable Sector's recommendation that Canada trial distributions to non-qualified donees to support collaboration between charities and others. ${ }^{155}$

\section{B. Addressing Conflicts of Interest}

There are many existing rules in Canada and the United States that deal with conflicts of interest and that could potentially address DAF provider and affiliate fees. For instance, state or provincial law duties of loyalty that apply to charity controllers would also incorporate a duty not to profit to the charity's detriment and to avoid or address conflicts

152. Philanthropy Australia, "Submission - Tax Deductible Gift Recipient Reform Opportunities" (3 August 2017) at 9, online (pdf): Australian Treasury <static.treasury.gov.au/uploads/sites/1/2017/12/PhilanthropyAustralia.pdf> [Philanthropy Australia, "Tax Deductible"]; see also, James Boyd \& Lee Partridge, "Collective Giving and its Role in Australian Philanthropy” (July 2017) at 50, online (pdf): Creative Partnerships Australia <www.communitybusinesspartnership.gov.au/wp-content/ uploads/2017/07/collective_giving_report_2017.pdf>.

153. Philanthropy Australia, "Tax Deductible", ibid.

154. Boyd \& Partridge, supra note 152 at 50; ibid at 7.

155. Catalyst for Change, supra note 4 at 97-99. 
of interest. ${ }^{156}$ Albeit concerns have been expressed in the United States that some states have watered these obligations down. ${ }^{157}$ Further, the United States Pension Protection Act 2006 reforms applied additional selfdealing rules to DAF providers, moving them closer to the treatment of private foundations. ${ }^{158}$ While the additional excise taxes on excess benefits transactions, taxable distributions and prohibited benefits appear largely aimed at benefits derived by donors, their advisors and their affiliates, ${ }^{159}$ the exception is IRC subparagraph $4958(\mathrm{f})(1)(\mathrm{F})$. This provision renders an investment advisor to a DAF sponsor (such as a financial services affiliate) a 'disqualified person' so that any transaction with the investment advisor would need to be examined to determine if the value of economic benefits provided exceeded the value of the services received. However, where services are provided at market rates and are simply more expensive because more assets are under management, this

156. See e.g. Johnny Rex Buckles, “The Federalization of Fiduciary Obedience Norms in Tax Laws Governing Charities: An Introduction to State Law Concepts and an Analysis of their Implications for Federal Tax Law" (2012) 4:2 Texas Tech School of Law Estate Planning \& Community Property Law Journal 197 at 199-200; Barry Reiter, Directors' Duties in Canada (Toronto: LexisNexis, 2016) ch 26, especially at 812-16.

157. Marion Fremont-Smith, Governing Nonprofit Organizations (Cambridge: Harvard University Press, 2004) at 234-36 [Fremont-Smith, Governing].

158. See e.g. Frederick J Gerhart, "Charitable Incentives and Charitable Reforms under the Pension Protection Act of 2006" (2007) 19:7 The Health Lawyer 21 at 26-27; Michael A Lehmann, "Major Changes for Exempt Organizations in the Pension Protection Act of 2006" (2007) 106: 1 Journal of Taxation 30 at 35-37.

159. This is especially true of $I R C$ sections 4966 (taxable distributions) and 4967 (prohibited benefits). IRC section 4958 might also apply to DAF sponsor transactions too, in that financial services affiliates may be "persons" who are "in a position to exercise substantial influence over the affairs of the” DAF sponsor: IRC, supra note 4, $\$$ 4958(f)(1)(A). 
type of provision may be less helpful. ${ }^{160}$

Similarly, section 188.1(4) of the ITA imposes a penalty where a charity confers an 'undue benefit' on a person. ${ }^{161}$ 'Undue benefit' is defined broadly to include rights and would apply where a DAF financial services affiliate does not deal at arms-length with the DAF provider or can be characterised as a member or settlor of the DAF provider. ${ }^{162}$ Several commentators have also suggested that the provision would apply to excessive remuneration for senior employees. ${ }^{163}$ Reasonable consideration for services rendered is excluded, ${ }^{164}$ such that, as for $I R C$ section 4958, there may be some uncertainty. Nevertheless, the provision could apply to DAF providers for giving, beyond consideration for services, the right to provide investment services or receive a bonus in relation to a larger sum of money than would otherwise be invested.

However, it is a fundamental requirement that charities have purposes for the achievement of public benefit, not private benefit. This is typically reflected in state or provincial law concerning the creation or validity of charitable corporations and trusts, ${ }^{165}$ as well as tax legislation. Thus, the United States income tax rules require that for a section 501(c)(3) organisation, none of the net earnings may "inure to the benefit of any private shareholder or individual" such that DAF sponsors must ensure

160. Treasury's 'initial contract' exception may also mean that if fees have been agreed by way of a formula under an initial contract, there is no excess benefit transaction, but this would only apply if the DAF affiliate was not a disqualified person before entering into the contract. Compare Marina Vishnepolskaya, "Compensation of Investment Advisors of Sponsoring Organizations Maintaining Donor-Advised Funds: Complying with the Excess Benefit Transaction Rules" (2010) 28:1 Journal of Taxation of Investments 3; 26 CFR, supra note 45, \$53.4958-4(a)(3).

161. ITA, supra note 20, s 188.1(4).

162. Ibid, s 188.1(5).

163. Robert Hayhoe \& Marcus Owens, "The New Tax Sanctions for Canadian Charities: Learning from the US Experience" (2006) 54:1 Canadian Tax Journal 57 at $75-76$.

164. ITA, supra note 20, s 188.1(5)(a).

165. As to Canada, see Gillen, Smith \& Waters, supra note 20 at 14.IV; In the United States context, see American Law Institute, Restatement of the Law of Charitable Nonprofit Organizations, TD No 1 (2016), $\$ 1.01$. 
that they are not "operated for the benefit of private interests such as designated individuals, the creator... or persons controlled, directly or indirectly, by such private interests" ${ }^{166}$ These rules are meant to stop DAF providers from providing benefits to people except where that provision is in pursuit of their purposes or incidental thereto. ${ }^{167}$ Likewise, to be a qualified donee "charitable foundation" under the Canadian ITA, a DAF provider must be "constituted and operated exclusively for charitable purposes" and it must be the case that "no part of the income of [the DAF provider] is payable to, or is otherwise available for, the personal benefit of any proprietor, member, shareholder, trustee, or settlor thereof". ${ }^{168}$

When it comes to addressing management and investment fees charged by DAF providers and their commercial affiliates, as both entities rely on those fees - directly or indirectly — on their ability to attract donors, it might also be anticipated that market mechanisms would limit fees. ${ }^{169}$ Donors are likely to jealously guard their advisory privileges, and so it is probably true that they will not exert much pressure on DAF providers to force other donors to distribute at higher rates such that market mechanisms are unlikely to deal with the deferral issue. ${ }^{170}$ However, donors might be expected to be far more interested in monitoring fees.

166. IRC, supra note $4, \$ 501$ (c)(3); 26 CFR, supra note 45, $\$ 1.501(\mathrm{c})(3)-1(\mathrm{~d})$ (1)(ii).

167. See e.g. Terry W Knoepfle, "The Pension Protection Act of 2006: A Misguided Attack on Donor Advised Funds and Supporting Organizations" (2009) 9:4 Florida Tax Review 221 at 224, 259-60.

168. ITA, supra note 20, s 149.1(1).

169. For discussion of market mechanisms to enforce the fiduciary duties of charity controllers in the related context where those charities rely on donations for their operations, see e.g. Johnny Rex Buckles, "Should the Private Foundation Excise Tax on Failure to Distribute Income Generally Apply to 'Private Foundation Substitutes'? Evaluating the Taxation of Various Models of Charitable Entities" (2010) 44:3 New England Law Review 493 at 511-12, 521 (with some reservations expressed about controlling conflicts of interest).

170. Compare ibid at 527-28. 
In summary, there seems no shortage of mechanisms for dealing with conflicts of interest, even if some fine-tuning of intermediate sanctions could be achieved to more clearly target the accumulation of assets to charge higher fees. An outsider's impression is that there is no significant need for more rules, but rather for better education about and enforcement of existing rules. Greater fee disclosure information would help, as would the ability to switch DAF providers, as noted for PuAFs in the Australian context. Many commentators have also noted patchy and inconsistent enforcement at the state level in the United States and the provincial level in Canada. ${ }^{171}$ Federal enforcement also currently appears weakened as the United States IRS is still reeling from the fallout over its targeting of politically aligned charities and is underfunded to regulate charities. ${ }^{172}$ While not so wounded, the chief Canadian regulator, the Canadian Revenue Agency, is also recovering from its imposition of increased political activity reporting and political activity audits, as well as from perceptions of bias in its role as charity regulator arising from its

171. As to Canada, see e.g. Catalyst for Change, supra note 4 at 64-65; Terry de March, "The Prevention of Harm Regulator" in Myles McGregorLowndes \& Bob Wyatt, eds, Regulating Charities: The Inside Story (New York: Routledge, 2017) 119 at 119-20. Compare Gillen, Smith \& Waters, supra note 20 at 14.VII. In the United States context, see e.g. FremontSmith, Governing, supra note 157 at 53; Evelyn Brody, "Whose Public? Parochialism and Paternalism in State Charity Law Enforcement” (2004) 79:4 Indiana Law Journal 937 at 946-50.

172. See e.g. Austl, Treasury, Treasury Inspector General for Tax Administration, "Review of Selected Criteria Used to Identify TaxExempt Applications for Review”, Final Report No 2017-10-054 (September 2017), online (pdf): The Treasury <www.treasury.gov/ tigta/auditreports/2017reports/201710054fr.pdf>; Marcus Owens, "Challenged Regulators" in Myles McGregor-Lowndes \& Bob Wyatt, eds, Regulating Charities: The Inside Story (New York: Routledge, 2017) 81 at 91 [Owens, "Challenged Regulators"]. 
role as a tax-collector. ${ }^{173}$

The Australian approach to enforcement involves a central role for the national charity regulator, the $\mathrm{ACNC}$, in coordinating activities at the state and federal level. Much of the recent Australian legislation also explicitly contemplates on-going information sharing between state and territory regulators and the ACNC. ${ }^{174}$ This is also reflected in division 150 of the ACNCAct, which permits the ACNC to disclose information to all other state/territory and Commonwealth government agencies (fiscal and non-fiscal) if that would assist those agencies to perform their functions or exercise their powers and would also promote the objects of the $A C N C$ Act. ${ }^{175}$ This coordinated approach is assisted by the fact that, unlike the Canadian and United States tax regulators, the ACNC has an institutional focus on charities. ${ }^{176}$ It also appears that the ACNC has (in relation to the IRS), and is using to a greater extent (in relation to the CRA), an ability to share information with state and territory attorneys-

173. See e.g. Adam Parachin, "Reforming the Regulation of Political Advocacy by Charities: From Charity Under Siege to Charity Under Rescue?" (2016) 91:3 Chicago-Kent Law Review 1047 at 1048, 1050-52; Bob Wyatt, "Reflections on the Long and Winding Road of Regulation" in Myles McGregor-Lowndes \& Bob Wyatt, eds, Regulating Charities: The Inside Story (New York: Routledge, 2017) 139 at 148-53; Catalyst for Change, supra note 4 at 109.

174. Consumer Acts Amendment Act 2017 (Vic), 2017/13, (Austl), s 4; Statutes Amendment (Commonwealth Registered Entities) Act 2016 (SA), 2017/24, (Austl), s 4; Red Tape Reduction Legislation Amendment Act 2017 (ACT), 2017/17, (Austl), s 14.

175. ACNC Act, supra note 51, division 150-40.

176. In relation to the IRS, contrast Owens, "Challenged Regulators", supra note 172 at 82; Elizabeth Boris \& Cindy Lott, "Reflections on Challenged Regulators" in Myles McGregor-Lowndes \& Bob Wyatt, eds, Regulating Charities: The Inside Story (New York: Routledge, 2017) 97 at 97. 
general and other regulators. ${ }^{177}$ When compared with the IRS approach to information gathering on registration and annually for small charities, that of the ACNC is superior. ${ }^{178}$

Better enabling national regulators to adopt a central coordination role for enforcement is broadly consistent with the North American discourse about charity regulation within a federation. ${ }^{179}$ That is because this approach leaves charity regulation fragmented between different levels of government and different agencies within a federation, but with room for centralisation of information gathering and reporting and greater coordination in governance enforcement. Although a tax regulator is always likely to be less focused on charity enforcement than a stand-alone charity regulator, there still appears to be some room for the IRS and CRA to improve their coordination of enforcement.

177. For the IRS, see Owens, "Challenged Regulators", supra note 172 at 83; Boris \& Lott, ibid at 106; Marion Fremont-Smith, "The Future of State Charities Regulation" (Paper delivered at the Columbia Law School Charities Regulation and Oversight Project Policy Conference on the Future of State Charities Regulation, New York, 2013) at 7-8, online: Columbia University Libraries <academiccommons.columbia.edu/ doi/10.7916/D82R3PQ2>. Thus, even after the Pension Protection Act of 2006, supra note 141, expanded the IRS' ability to disclose information to state regulators, it seems that information sharing arrangements between the IRS and state regulators are virtually non-existent: American Law Institute, Restatement of the Law of Charitable Nonprofit Organizations, TD No 3 (2019), $\$ 5.03 \mathrm{cmt}$ b. It appears the CRA has the ability to share information, but needs to use that ability further, a matter partly due to provincial inaction: see Catalyst for Change, supra note 4 at 59-60; de March, supra note 171 at 127-28.

178. Evelyn Brody \& Marcus Owens, "Exile to Main Street: The IRS's Diminished Role in Overseeing Tax-Exempt Organizations” (2016) 91:3 Chicago-Kent Law Review 859 at 881-84.

179. Lloyd Mayer, "Fragmented Oversight of Nonprofits in the United States: Does it Work - Can it Work?” (2016) 91:3 Chicago-Kent Law Review 937 at 944-45; Lloyd Mayer \& Brendan Wilson, "Regulating Charities in the Twenty-First Century: An Institutional Choice Analysis" (2010) 85:2 Chicago-Kent Law Review 479. 


\section{Conclusion}

Although the Australian experience with sub-funds or DAFs is still relatively niche, the Australian regulatory regime and discourse provide some guidance. First, as DAFs - by their very nature - involve a degree of temporal deferral, they raise issues of fairness and efficiency about the intergenerational distribution of public benefit that could threaten social cohesion if not addressed. Intergenerational justice is a potential normative basis for answering how the balance should be set between benefit for the current versus future generations. It is possible to implement payout rules for DAF providers that are consistent with some interpretations of intergenerational justice, and the Australian PuAF payout rules indicate that a moderate payout requirement is unlikely to dissuade donations to DAFs and would not impose too onerous an administrative burden. However, the Australian trend of a declining PuAF payout percentage suggests that a higher payout rate may be preferable and a higher rate would start to resemble proposals from North American commentators for contributions to be spent within a certain timeframe. It would, however, be administratively simpler, thus retaining one of the benefits of DAFs.

Another approach that is better aligned with charity independence and pluralism and with the flexibility benefits of DAFs is to impose on DAF directors and trustees (and through them, DAF donors) a duty to give genuine consideration to principles of intergenerational justice when exercising discretionary powers over the distribution of DAF assets. Accountability and enforcement would be critical to such an approach, and the current regulatory climate in the United States does not appear conducive. Canada may have more leeway, especially if the Special Senate Committee on the Charitable Sector's recommendations are followed, along with the comments below on regulation and conflicts of interest. The genuine consideration duty approach could be twinned with a payout safe-harbour to reduce administration costs.

Second, a prohibition on circular distributions can be implemented relatively easily and seems preferable to more general anti-avoidance rules. However, the Australian experience demonstrates that there is likely to be value in permitting an ability to switch DAF providers and to switch the 
status of a whole pool of funds from a private to a public foundation (and vice versa), provided this is subject to regulatory oversight. Additionally, in rural, regional and remote areas, a community foundation will often be the key charity. If it cannot accept contributions from private foundations or other DAFs, this may mean that rural, regional and remote communities miss out. Some consideration therefore needs to be given to an exception for distributions to community foundations which have a purpose primarily linked to such a region.

Finally, to better address conflicts of interest posed by financial services-affiliated DAF providers, greater thought should be given to improved charity regulators rather than introducing new rules. The report of the Canadian Special Senate Committee on the Charitable Sector, in particular, raises hopes for improved regulatory cooperation in Canada - a major change in Australia with the introduction of the ACNC. However, a core institutional focus on charities is also key and is much harder to achieve within a tax authority. 